\title{
Standardized Administration Practical Exploration of Higher Vocational Colleges' Sino-foreign Education Joint Project
}

\author{
Yan Ma \\ Department of Computer and Information Engineering \\ Zhejiang University of Water Resources and Electric Power \\ Hangzhou, China \\ mayan@zjweu.edu.cn
}

\begin{abstract}
Economic globalization promotes the internationalization of higher education, and higher vocational colleges have carried out more and more Sino-foreign cooperative education projects. Zhejiang Water Conservancy and Hydropower College launched specialized Higher Education Joint Project in Information Technology between our college and Nelson Marlborough Institute of Technology, New Zealand in 2007. After a few years of practice and exploration, we have made a number of standardized administration experiences. In accordance with the relative national laws and regulations, we explored joint development of curriculums and training plans, standardization of implementing the project, perfect teaching implementation, strict teaching management and high quality faculty. Those methods guaranteed the standardization administration of Sino-foreign education joint project.
\end{abstract}

Keywords- standardization administration; sino-foreign education joint project; higher vocational college

\section{THE BACKGROUND OF SINO-FOREIGN EDUCATION JOINT PROJECT}

\section{A. Globalization promotes the internationalization of higher education}

As the economic globalization quickens its step, the international communication in economy and culture is developing in depth and breadth. There is an urgent need of a large number of high-quality talents who have international views and are familiar with international rules, meanwhile can participate in international affairs and international competition[1-2].

However, a country or a region with the existing educational resources is difficult to cultivate all kinds of high quality comprehensive international talents. Under this big background, internationalization of higher education becomes inevitable.

\section{B. Shortage of quality resources for higher education in Zhejiang Province}

In recent years, higher education in Zhejiang Province is developing rapidly, and college size and college level have made significant progress. However, there still is a large gap between the talents who are trained under the higher education and economic and social development needs of high-level talents. Especially, trained international and integrated talents can't meet the social requirements. Therefore, it is imperative to introduce foreign high-quality education resources to cover the shortage.

Since 2000, more and more higher vocational education joint projects came into people's sight. In this paper, we share our practice exploration experiences of Sino-foreign education joint project.

\section{THE PURPOSES OF THE JOINT PROJECT}

Through Sino-foreign education joint project, it makes us expand educational horizons, broaden educational ideas, promote professional and curriculum reform. It helps teachers change educational ideals, promote the restructuring and updating of teachers' knowledge, meanwhile, improve teaching methods and teaching ability especially in bilingual teaching ability. So the teachers' comprehensive quality has obvious improved[3].

Furthermore, it integrates domestic and abroad excellent teaching resources, trains students with an international perspective, and improves students' comprehensive quality and competitiveness in employment. What's more, more and more communication between domestic and abroad similar college develops an education and teaching management team who thoroughly understand rules of international cooperation and improve the teaching quality. 


\section{STANDARDIZING ADMINISTRATION ACCORDING TO LAWS AND REGULATIONS}

\section{A. Running the project according to laws}

In early 2006, our college applied the specialized higher education joint project in information technology that cooperates with New Zealand Nelson Marlborough institute of technology. We got the official approval from Zhejiang Province education department in November, 2006. The application for an extension of this project is approved in 2009, and the second extension of this project was approved again in 2012.After approval of Zhejiang Provincial Education Department, we can run this IT joint project until 2018.

In the cooperative education process, our college is strict in compliance with "The People's Republic of China Regulations for Sino-foreign cooperation in running schools ", "The People's Republic of China Regulations for implementation of Sino-foreign Cooperation in Running Schools" and other relevant provisions. According to the actual situation of our college, we established "Zhejiang Water Conservancy and Hydropower College Sino-foreign joint project management regulations"(Trial), which regulates the operation and management of the joint project and ensures the steady and healthy development of the project.

\section{B. Standardization of implementing the project}

In the process of cooperative education, our college carries out the joint project in strict accordance with the relevant provisions and requirements of higher authorities, and submits the annual performance report to the Zhejiang Province Education Department every year.

According to the actual situation of our college cooperation education project, we established and improved the teaching management, the teachers' selection, the roll management, the use of funds, the student management and other aspects' rules and regulations. They normalize the cooperation in running schools and guarantee project normal operation on the premise of constantly improving the quality of teaching.

According to the IT project cultivation goals, which are agreed by our college and NMIT, we developed training plan of information technology specialty through adequate consultations between us. In addition to courses in the ministry of education requirements, our college imported 16 core courses from NMIT. Among these 16 courses, there are 7 courses taught by foreign teachers and 9 courses (Bilingual courses) taught by Chinese teachers.

\section{Perfect teaching implementation}

There are 16 core courses of IT specialty and one basic course. 7 courses are foreign teacher's courses and 9 courses are bilingual courses. $88.2 \%$ courses are imported teaching materials (as shown in Table I ).
TABLE I. THE MAIN COURSES OF JOINT EDUCATION PROJECT IN IT

\begin{tabular}{|c|c|c|c|c|c|c|}
\hline \multirow{2}{*}{ Type } & \multicolumn{4}{|c|}{ Courses } \\
\cline { 2 - 7 } & \multicolumn{2}{|c|}{$\begin{array}{c}\text { Chinese } \\
\text { course(s) }\end{array}$} & \multicolumn{2}{c|}{$\begin{array}{c}\text { Imported } \\
\text { course(s) }\end{array}$} & \multicolumn{2}{c|}{ Total } \\
\cline { 2 - 7 } & $\begin{array}{c}\text { Amo } \\
\mathrm{u} \\
-\mathrm{nt}\end{array}$ & $\begin{array}{c}\text { Propor } \\
\mathrm{t} \\
-\mathrm{i}\end{array}$ & $\begin{array}{c}\text { Amo } \\
\mathrm{u} \\
-\mathrm{nt}\end{array}$ & $\begin{array}{c}\text { Propor } \\
\mathrm{t} \\
-\mathrm{ion}\end{array}$ & $\begin{array}{c}\text { Amo } \\
\mathrm{u} \\
-\mathrm{nt}\end{array}$ & $\begin{array}{c}\text { Proport } \\
- \text {-ion }\end{array}$ \\
\hline $\begin{array}{c}\text { Basic } \\
\text { courses }\end{array}$ & 5 & $83.3 \%$ & 1 & $16.7 \%$ & 6 & $100 \%$ \\
\hline $\begin{array}{c}\text { Profession } \\
\text { al courses }\end{array}$ & 2 & $11.8 \%$ & 15 & $88.2 \%$ & 17 & $100 \%$ \\
\hline
\end{tabular}

1) Language teaching courses

There are about 20 to 30 students in English courses' class. Considering the needs of the students oversea studying, we established the autonomous teaching mode with the core of students' interactions so that students can strengthen the communicative ability. With different tasks and strategies, students learn the knowledge, ability and quality and this way highlights student participation and practicality of teaching content. While in the care of the group goals, we pay attention to the individual differences so that students' personality can be fully developed. It can improve students' language application ability especially in listening and speaking. And it also can lay a solid foundation for students learning bilingual courses and foreign courses.

\section{2) Bilingual teaching courses}

We select some teachers who are good at English and have professional ability. They use English and Chinese to write lesson plans. When they teach courses in the classroom, $30 \%$ to $50 \%$ of the information is used in English. According to the different kinds of courses, teachers use modern education technical methods such as multimedia assisted teaching.

The teaching methods are not formalized, greatly mobilize students to participate in the courses and arouse students' learning initiative. In the class, teachers and students interact constantly, that means teachers momentarily answer students' questions and also continually ask questions to the students. Therefore, the classroom atmosphere is very active. On the one hand, it arouses the students' interest in learning. On the other hand, students are willing to keep pace with the course schedule. As a result, teaching effect and learning effects are quite good.

Students should answer the questions almost in English, and also use English to complete several assignments, while they use English to answer more than $50 \%$ of the examination contents.

In all courses, teachers adopt process assessment. In other word, there are several different methods to evaluate the result of students' during the whole process of one course. For example, Internet Design Principle has two practical operation reports, one assignment designing a static website, and one final examination. Through this way, students can not only learn the knowledge of the course, but also master the practical skills. Moreover, students think that the evaluation procedure can assess their learning process and 
the evaluation method can check their ability of learning the course.
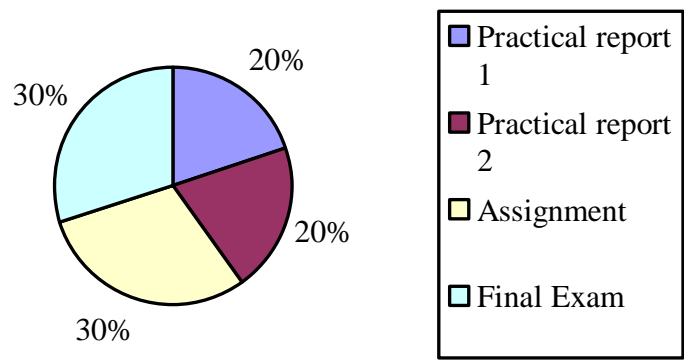

Figure 1. The assessment of Internet Design Principle

\section{3) Foreign teachers' courses}

The chief course instructors are selected by the NMIT, and each course has two Chinese teaching assistants. The assistants will do their assistant work in class, be responsible for answering questions after class and finally participate in students' achievement assessment.

Like with bilingual courses, foreign teachers also used 2 to 3 tasks or assignments to evaluate the result of students' study. In their class, teachers and students discuss particularly actively, and teachers don't tell students the right answers but guide students how to do their tasks. Most students are not suited to it at the beginning of the foreign courses, but they like this mode of study soon, and then they start to think the problems and requirements. It is exactly the pursuing goal of traditional education that teaching students how to learn.

\section{Strict teaching management}

The teaching management regulations and the teaching files are relatively complete. We have established regulations and rules such as "Sino-foreign education joint project management approaches", "Sino-foreign education joint project foreign teachers and teaching assistants management approaches", "The international institute of education teachers' employment and management approaches", "The international institute of education final examination's job specifications and requirements" and "The international institute of education graduation practice management measures". These regulations and rules make specific provisions for teachers' employments, teaching organization, teaching evaluation, theoretical teaching and practical teaching, etc.

We use process management in each teaching step. The teaching assessment center of our college and the steering group of IIE will check and spot check the process of teaching. If they find some problems, they will communicate with teachers in a timely and effective manner in order to ensure smoothly and orderly running of the daily teaching work.

\section{E. High quality faculty}

Sino-foreign education joint project in information technology has a stable administrative and professional teaching team, and the team leader is responsible for the project management.

In this joint project, there are 10 Chinese administrative staffs and 7 NMIT administrative staffs. In Chinese administrative staffs, $30 \%$ are full-time administrative staffs. And $42.9 \%$ are full-time administrative staffs in NMIT administrative team. Among all those staffs, $57.1 \%$ of fulltime administrative staffs have senior titles and $25 \%$ of them have

intermediate titles (as shown in Table II ).

In our professional team, there are 26 teachers from different department. Among them, there are 19 Chinese teachers (including 9 basic course teachers) and 7 NIMT teachers. 5 teachers from NMIT are associate professor. There are 10 Chinese professional teachers participating in the teaching process, including 1 professor, 2 associate professors and 7 lecturers. 60\% teachers are masters, and $20 \%$ teachers are doctors (as shown in Table III).

Ten Chinese teachers (including English teachers) have been to New Zealand for visiting and studying and then they have learned lots of useful teaching experiences from New Zealand higher education. Seven teachers of the IT team have the short-term training in NMIT for learning IT professional teaching experiences. What' more, one teacher has studied in Sweden for two years and is familiar with western teaching style, one teacher has visited and studied in USA eight months.

Foreign teachers and bilingual teachers not only have extensive teaching experiences, but also have corporate training experiences. They are also called the dualqualification teachers. Such practical work experiences are especially helpful to students learning practical skills.

Under such teachers' team teaching, students can learn professional knowledge and skills and have a good experience in cross-cultural communication at the same time. As a consequence, students really benefit from education internationalization.

TABLE II. THE ADMINISTRATIVE STAFF OF JOINT EDUCATION PROJECT IN IT

\begin{tabular}{|c|c|c|c|c|c|}
\hline \multirow{2}{*}{ Type } & \multicolumn{2}{|c|}{ Chinese teacher(s) } & \multicolumn{2}{c|}{ Foreign teacher(s) } & Total \\
\cline { 2 - 6 } & Amount & Proportion & Amount & Proportion & Amount \\
\hline $\begin{array}{c}\text { Basic } \\
\text { courses }\end{array}$ & 9 & $90 \%$ & 1 & $10 \%$ & 10 \\
\hline $\begin{array}{c}\text { Professional } \\
\text { courses }\end{array}$ & 10 & $62.5 \%$ & 6 & $37.5 \%$ & 16 \\
\hline $\begin{array}{c}\text { Senior title } \\
\text { Intermediate } \\
\text { title }\end{array}$ & 6 & $50 \%$ & 6 & $50 \%$ & 12 \\
\hline \begin{tabular}{c} 
Junior title \\
\hline
\end{tabular} & 0 & $92.9 \%$ & 1 & $7.1 \%$ & 14 \\
\hline
\end{tabular}


TABLE III. THE PROFESSIONALTEACHERS OF JOINT EDUCATION PROJECT IN IT

\begin{tabular}{|c|c|c|c|c|c|}
\hline \multirow{2}{*}{ Type } & \multicolumn{2}{|c|}{$\begin{array}{c}\text { Full-time } \\
\text { administrative staff }\end{array}$} & \multicolumn{2}{c|}{$\begin{array}{c}\text { Part-time } \\
\text { administrative staff }\end{array}$} & Total \\
\cline { 2 - 6 } & Amount & Proportion & Amount & Proportion & Amount \\
\hline $\begin{array}{c}\text { Full- } \\
\text { time/Part- } \\
\text { time }\end{array}$ & 6 & $35.3 \%$ & 11 & $64.7 \%$ & 17 \\
\hline $\begin{array}{c}\text { Chinese } \\
\text { staff }\end{array}$ & 3 & $30 \%$ & 7 & $70 \%$ & 10 \\
\hline $\begin{array}{c}\text { NMIT staff } \\
\text { Nhing }\end{array}$ & 3 & $42.9 \%$ & 4 & $57.1 \%$ & 7 \\
\hline $\begin{array}{c}\text { Senior title } \\
\text { title }\end{array}$ & 4 & $57.1 \%$ & 3 & $42.9 \%$ & 7 \\
\hline $\begin{array}{c}\text { Intermediate } \\
\text { Junior title }\end{array}$ & 0 & $0 \%$ & 2 & $100 \%$ & 2 \\
\hline
\end{tabular}

\section{CONCLUSION}

After six years practice and exploration, we have made a number of standardized administration experiences mentioned above. High quality faculty is particularly important factors that affect the success or failure of the joint project. In 2010, the first batch of students graduated and ten of seventy-one students went to NMIT for continuing to learn (as shown in Table IV). Most of our graduates chose to be employed in the domestic. For three consecutive years, employment situations are in good condition. Of course, there is still a long way to improve the teaching quality of cooperative education for us.

TABLE IV. THE INFORMATION OF IT GRADUATES

\begin{tabular}{|c|c|c|c|c|c|}
\hline \multirow{2}{*}{ Year } & \multicolumn{5}{|c|}{ Distribution of graduates } \\
\cline { 2 - 6 } & $\begin{array}{c}\text { Tota } \\
\boldsymbol{l}\end{array}$ & $\begin{array}{c}\text { Domestic } \\
\text { Undergraduat } \\
\boldsymbol{e}\end{array}$ & $\begin{array}{c}\text { Study } \\
\text { aboard }\end{array}$ & Employed & Unemployed \\
\hline 2010 & 71 & 6 & 10 & 55 & 0 \\
\hline 2011 & 68 & 6 & 5 & 57 & 0 \\
\hline 2012 & 31 & 2 & 2 & 27 & 0 \\
\hline
\end{tabular}

\section{ACKNOWLEDGMENT}

This paper is the derivative of work report of "Specialized Higher Education Joint Project in Information Technology between Zhejiang Water Conservancy \& Hydropower College and Nelson Marlborough Institute of Technology, New Zealand" which is rates as one of Zhejiang Sino-foreign education joint demonstration project in 2013. I thank leaders of International Institute of Education for giving me the opportunity of participating in the project management. And I also thank all members of IT joint project for our joint efforts.

\section{REFERENCES}

[1] Lianxiao Wang, "Quality assurance system construction of higher vocational college's Sino-foreign cooperative education", Adult Education, vol.33, pp. 40-43, 2013.

[2] Wenjuan Lu, Kebing Zhu, "A study of bilingual teaching model in the context of Sino-Foreign cooperation in running schools", Theory and Practice of Education, vol.33, pp. 15-17, 2013.

[3] Jianting Ren, "A study of quality assurance system of education institutions' Sino-foreign cooperative projects", Education Teaching Forum, No.4, pp. 8-9, 2013 